\title{
Colposcopic evaluation of cervix with abnormal papsmear findings: prospective analytical study at our tertiary care centre
}

\author{
Bhawna Verma $^{1 *}$, Radha Rastogi ${ }^{1}$, Dipti Srivastava ${ }^{2}$, Saroj Saharan $^{1}$
}

\begin{abstract}
${ }^{1}$ Department of Obstetrics and Gynaecology, RNT Medical College, Udaipur, Rajasthan, India
${ }^{2}$ Department of Obstetrics and Gynaecology, Govt. Hospital, Chittorgarh, Rajasthan, India
\end{abstract}

Received: 01 March 2021

Accepted: 02April 2021

\section{*Correspondence:}

Dr. Bhawna Verma,

E-mail: docbhawna27@gmail.com

Copyright: $\odot$ the author(s), publisher and licensee Medip Academy. This is an open-access article distributed under the terms of the Creative Commons Attribution Non-Commercial License, which permits unrestricted non-commercial use, distribution, and reproduction in any medium, provided the original work is properly cited.

\section{ABSTRACT}

Background: Pap test has been successful in reducing the incidence of cervical cancer by $80 \%$ and mortality by $70 \%$. Any women with a cytologic specimen suggesting the presence of HSIL on Pap smear should undergo colposcopy and dissected biopsy. Prevention of invasive cancer by early detection and treatment of cervical intraepithelial neoplasia (CIN) currently offers the most cost effective, long term strategy for cervical cancer control. The aim of study was to minimise disagreements and make colposcopy assessment quick, accurate and easy for follow-up.

Methods: Prospective analytical study of 300 gynaecological patients with abdominal Pap smear findings between June 2020 to Dec 2020 at R.N.T. Medical College, Udaipur. All of them were subjected to colposcopy and dissected biopsy from the abdominal areas. The incidence of CIN/invasive carcinoma was calculated by proportion/percentage. Results: Incidence of invasive carcinoma was $<1 \%$ but the incidence of premalignant lesion CIN was high (20.9\%), CIN 2/3 and CIS were present in 6.9\%.

Conclusions: Patients with persistent inflammation pap smear can harbour high proportion of CIN and hence these patients need further evaluation through colposcopy.

Keywords: Colposcopy cervical intraepithelial neoplasia, Invasive cancer, Reid colposcopy index

\section{INTRODUCTION}

Chronic inflammation, either specific or non-specific, has been shown to be associated with malignancy and was thought to be one of the factors responsible for carcinogenesis. Persistent inflammation leads to increased cellular turnover, especially in the epithelium, and provides a selection pressure that results in the emergence of cells that are at a high risk for malignant trans formation. ${ }^{1}$ Inflammatory Pap smear is the most common report the gynecologist receives even when the cervix appears normal. The original Papanicolau classification of class 2 smears denotes inflammation and the recommendation is to repeat the smear after treating the infection. ${ }^{2}$ However, this does not specify the type of infection and the presenter porting of Pap smear by the
Bethesda system reports on specific infections and classifies it under benign cellular changes. ${ }^{3}$ The cervical screening algorithm for benign cellular changes recommends treatment of infection if indicated and performing a repeat Pap smear in 4 to 6 months time and if the inflammatory changes persist, to subject the patient to colposcopy. ${ }^{4}$

In practice, however, this is not always followed, especially in developing countries. The significance of cervical cytology with atypia has been extensively studied. There is a great controversy regarding the optimal management of women with persistent inflammatory changes without atypia, some considering it less likely to be associated with dysplasia and others recommending further evaluation as it is associated with 
a high incidence of cervical intraepithelial neoplasia (CIN) ${ }^{5-7}$

Hence, we have undertaken this study with the objectives to study the colposcopic features in the cervices of persistent inflammatory cellular changes on Pap smear, to study epithelial cell abnormalities by colposcopic biopsy of abnormal areas in such cases and to determine the existence of significant cervical intraepithelial lesions or invasive carcinoma inpatients with persistent inflammatory Pap smear.

\section{METHODS}

This is a prospective analytical study conducted in the Department of Obstetrics and Gynecology, RNT Medical College, Udaipur between August 2006 and June 2008.

One hundred and fifty women who showed persistent inflammatory changes on Pap smear were included in the study.

Patients with persistent inflammatory changes with atypical ordysplastic cells, patients with Diabetes mellitus, pregnant women and patients with previous cervical surgery were excluded. The study was approved by the Institute Scientific and Ethical Committee.

Patients with a report of inflammatory Pap smear were selected at random for initial recruitment. These patients were advised to use clotimazole or betadine vaginal pessaries for a minimum of 6 days. Those with a clinical diagnosis of chronic pelvic inflammatory disease and showing inflammatory Pap smear were given Doxycycline and Metronidazole for a minimum period of 14 days along with vaginal pessaries.

A repeat Pap smear was performed after a period of 2 weeks with Ayer's wooden spatula. No preparation of the cervix was undertaken at the time of sampling and women were not menstruating or using any vaginal douche or vaginal contraceptives at the time of sampling. If inflammatory cellular changes were reported again on the repeat Pap smear, these patients were subjected to colposcopic examination after taking informed consent.

The woman was kept in a dorsal position and the cervix was exposed by inserting a Cusco's speculum. Excess mucus was wiped off with a cotton swab soaked in saline. Five percent acetic acid was applied to the cervix and it was visualized using a binocular colposcope (M/s Olympus Optical Co. Ltd., Tokyo, Japan) under 40X magnification. Biopsies were taken from the abnormal areas (aceto white areas and vascular abnormalities like fine punctuations, coarse punctuations, mosaic and areas $1 / 11 / 2021$ colposcopic evaluation of cervix with persistent inflammatory Pap smear: A prospective analytical study showing atypical vasculature) and an endo cervical curettage was performed. All the specimens were subjected to histopathological examination. The incidence of pre-malignant and malignant lesions was calculated as percentages.

\section{RESULTS}

The mean age was 37 years and the mean parity was 2.6. The most common symptom was vaginal discharge followed by pelvic pain and in $45 \%$ of the patients the clinical diagnosis was pelvic inflammatory disease. Abnormal uterine bleeding and erosion of the cervix also contributed to inflammatory smear in approximately $20 \%$ of the patients (Table 1).

Table 1: Clinical profile.

\begin{tabular}{|c|c|c|}
\hline $\begin{array}{l}\text { Clinical } \\
\text { characteristic }\end{array}$ & Number & Percentage \\
\hline Mean age & 37 years & \\
\hline Mean parity & 2.6 & \\
\hline \multicolumn{3}{|l|}{ Symptomatology } \\
\hline $\begin{array}{l}\text { White discharge per } \\
\text { vaginum }\end{array}$ & 134 & 44.7 \\
\hline Pelvic pain & 82 & 27.3 \\
\hline AUB & 36 & 12 \\
\hline Post-coital bleeding & 18 & 6 \\
\hline $\begin{array}{l}\text { Mass descending per } \\
\text { vaginum }\end{array}$ & 12 & 4 \\
\hline $\begin{array}{l}\text { Post-menopausal } \\
\text { bleeding }\end{array}$ & 10 & 3.3 \\
\hline Dysmenorrhea & 8 & 2.7 \\
\hline \multicolumn{3}{|l|}{ Clinical diagnosis } \\
\hline PID & 104 & 34.7 \\
\hline AUB & 64 & 21.3 \\
\hline Cervix erosion & 62 & 20.7 \\
\hline Unhealthy cervix & 40 & 13.3 \\
\hline $\begin{array}{l}\text { Uterovaginal } \\
\text { prolapsed }\end{array}$ & 12 & 4 \\
\hline Ovarian cyst & 10 & 3.3 \\
\hline Fibroid uterus & 8 & 2.7 \\
\hline
\end{tabular}

The colopscopic features of patients with persistent inflammatory pap smears (Table 2). The most common feature was aceto whiteness $(41.3 \%)$ followed by a combination of aceto whiteness and vascular abnormality $(24.7 \%)$. Colposcopy was normal in nine patients and hence no biopsy was taken. Erosion was confirmed by colposcopy in $12 \%$ of the patients. Biopsy was also not performed when the margins of erosion were regular and these accounted for five cases.

The correlation of inflammatory Pap smear with coloposcopic biopsy results (Table 3 ). The most common biopsy result in patients with inflammatory pap smear was chronic cervicitis (28.7\%). Human papilloma virus (HPV) lesions accounted for $21.2 \%$ CIN 1 for $14.7 \%$ and CIN $2 / 3$ for $4.4 \%$ of the cases. The two cases of carcinoma in situ and one case of invasive carcinoma also showed non-specific inflammation on Pap test. Ten percent (14/150) did not require biopsy. 
Table 2: Colposcopic features of patients with inflammatory Pap smear.

\begin{tabular}{|llllll|}
\hline Inflammatory Pap smear & Normal & Erosion & $\begin{array}{l}\text { Acetowhite } \\
\text { areas }\end{array}$ & $\begin{array}{l}\text { Vascular } \\
\text { abnormalities }\end{array}$ & $\begin{array}{l}\text { Acetowhite areas } \\
\text { and vascular } \\
\text { abnormalities }\end{array}$ \\
\hline $\begin{array}{l}\text { Non-specific inflammation } \\
(\mathbf{n}=\mathbf{2 7 6})\end{array}$ & $14(5.07)$ & $36(13.04)$ & $106(38.40)$ & $51(18.47)$ & $69(25)$ \\
\hline Bacterial vaginosis $(\mathbf{n}=\mathbf{1 2})$ & 2 & - & 2 & 2 & 6 \\
\hline Candida albicans $(\mathbf{n = 6})$ & 2 & - & 2 & - & 2 \\
\hline $\begin{array}{l}\text { Trichomonas vaginalis } \\
(\mathbf{n}=\mathbf{6})\end{array}$ & - & - & 4 & - & 2 \\
\hline Total $(\mathbf{n}=\mathbf{3 0 0})$ & $18(6)$ & $36(12)$ & $114(38)$ & $53(17.66)$ & $79(26.33)$ \\
\hline
\end{tabular}

Table 3: Correlation of inflammatory Pap smear with colposcopic biopsy.

\begin{tabular}{|c|c|c|c|c|c|c|c|c|c|c|}
\hline $\begin{array}{l}\text { Persistent } \\
\text { inflammatory } \\
\text { Pap smear } \\
\text { (Cytodiagnosis) }\end{array}$ & $\begin{array}{l}\text { No } \\
\text { biopsy }\end{array}$ & $\begin{array}{l}\text { Normal } \\
\text { tissue }\end{array}$ & SM & $\begin{array}{l}\text { Chronic } \\
\text { cervicitis } \\
\text { (CC) }\end{array}$ & $\begin{array}{l}\text { SM } \\
+\mathrm{CC}\end{array}$ & $\begin{array}{l}\text { HPV } \\
\text { lesions }\end{array}$ & CIN1 & CIN2 & $\begin{array}{l}\text { Cain } \\
\text { situ }\end{array}$ & Invasive Ca \\
\hline $\begin{array}{l}\text { Non-specific } \\
\text { inflammation } \\
(\mathrm{n}=276-24) \\
(\mathbf{2 5 2})\end{array}$ & 24 & 34 (14) & $4(2)$ & $70(28)$ & 34 (14) & $\begin{array}{l}58 \\
(23)\end{array}$ & $\begin{array}{l}36 \\
(15)\end{array}$ & $\begin{array}{l}10 \\
(4)\end{array}$ & $4(2)$ & $2(0.7)$ \\
\hline $\begin{array}{l}\text { Bacterial } \\
\text { vaginosis }(n=8)\end{array}$ & 2 & 2 & & 4 & & & 2 & 2 & & \\
\hline $\begin{array}{l}\text { Candida } \\
\text { albicans }(n=6)\end{array}$ & 2 & 2 & & & & & & & & \\
\hline $\begin{array}{l}\text { Trichomonas } \\
\text { vaginalis }(n=3)\end{array}$ & & & & 2 & 2 & & 2 & & & \\
\hline $\begin{array}{l}\text { Total biopsies } \\
(\mathbf{3 0 0 - 2 8}) \\
(\mathbf{n}=\mathbf{2 7 2})\end{array}$ & 28 & $\begin{array}{l}38 \\
(13.9)\end{array}$ & $\begin{array}{l}4 \\
(1.5)\end{array}$ & $78(28.7)$ & $\begin{array}{l}36 \\
(13.2)\end{array}$ & $\begin{array}{l}58 \\
(21.2)\end{array}$ & $\begin{array}{l}40 \\
(14.7)\end{array}$ & $\begin{array}{l}12 \\
(4.4)\end{array}$ & $\begin{array}{l}4 \\
(1.5)\end{array}$ & $2(0.7)$ \\
\hline
\end{tabular}

Table 4: Correlation of clinical symptoms and colposcopic findings.

\begin{tabular}{|c|c|c|c|c|c|c|}
\hline & Colpose & c findings & & & & \\
\hline Clinical symptom & Normal & Erosion & $\begin{array}{l}\text { Acetowhite } \\
\text { areas(AW) }\end{array}$ & $\begin{array}{l}\text { Vascular } \\
\text { abnormality(VA) }\end{array}$ & $\mathbf{A W}+\mathbf{V A}$ & Total \\
\hline Vaginal discharge(n=134) & 6 & 26 & $46(34)$ & 18 & $38(28)$ & 134 \\
\hline Pelvic pain $(n=82)$ & 6 & 6 & $38(46)$ & 12 & $20(24)$ & 82 \\
\hline AUB $(\mathbf{n}=18)$ & 2 & - & 14 & 14 & 6 & 36 \\
\hline Post-coital bleeding ( $\mathrm{n}=18)$ & - & 4 & 8 & - & 6 & 18 \\
\hline Mass per vaginum $(\mathrm{n}=12)$ & - & - & 6 & 4 & 2 & 12 \\
\hline $\begin{array}{l}\text { Post-menopausal } \\
\text { bleeding }(n=10)\end{array}$ & - & - & 6 & 2 & 2 & 10 \\
\hline Dysmennorrhea $(\mathrm{n}=8)$ & 4 & - & 4 & - & - & 8 \\
\hline Total $(\mathrm{n}=\mathbf{3 0 0})$ & $18(6)$ & $36(12)$ & $122(40.7)$ & $50(16.7)$ & $74(24.7)$ & 300 \\
\hline
\end{tabular}

The correlation between clinical symptomatology and colposcopic features (Table 4). The most common colposcopic feature is aceto whiteness followed by a combination of acetowhite areas and vascular abnormality, irrespective of the symptoms. Of the patients who presented with pelvic pain, $46 \%$ showed ace to white areas and $24 \%$ showed a combination of ace to white areas and vascular abnormality. This is slightly higher than the patients presenting with vaginal discharge per vaginum who showed ace to white areas in $34 \%$ of the cases and a combination of acetowhite areas and vascular abnormality in $28 \%$ of the cases. Erosion was more common in patients with vaginal discharge than in those with pelvic pain. 
The results of colposcopic biopsy in correlation with symptomatology (Table 5). The patient with invasive carcinoma presented with pelvic pain and two patients with carcinoma in situ presented with post-coital bleeding. In patients who presented with vaginal discharge, the most common diagnosis was chronic cervicitis followed by HPV lesions in $17 \%$ and CIN 1 in another $17 \%$ of the cases. Patients with abnormal uterine bleeding also showed a significantly increased incidence of CIN (22.2\%).
Of the benign lesions, chronic cervicitis and HPV changes were common. Acanthosis, koilocytosis, chronic cervicitis with koilocytosis, squamous metaplasia with koilocytosis, acanthosis with koilocytosis and koilocytic atypia were grouped under HPV changes. The incidence of invasive carcinoma was $<1 \%$.But, the incidence of premalignant lesions was high (20.9\%). CIN 2/3 and carcinoma in situ together contributed to $6.9 \%$ of the cases.

Table 5: Clinical symptoms and colposcopic biopsy results.

\begin{tabular}{|c|c|c|c|c|c|c|c|c|c|c|}
\hline $\begin{array}{l}\text { Clinical } \\
\text { symptoms }\end{array}$ & $\begin{array}{l}\text { No } \\
\text { biopsy }\end{array}$ & $\begin{array}{l}\text { Norma } \\
\text { I tissue }\end{array}$ & $\begin{array}{l}\text { Squamous } \\
\text { metaplasia } \\
(\mathrm{SM})\end{array}$ & $\begin{array}{l}\text { Chronic } \\
\text { cervicitis } \\
\text { (CC) }\end{array}$ & $\begin{array}{l}\text { SM+ } \\
\text { CC }\end{array}$ & $\begin{array}{l}\text { HPV } \\
\text { lesions }\end{array}$ & CIN1 & CIN2 & CIN3 & Invasion \\
\hline $\begin{array}{l}\text { Vaginal } \\
\text { discharge } \\
(n=124)\end{array}$ & 16 & 24 & 2 & 34 & 6 & 24 & $\begin{array}{l}24 \\
(17.9)\end{array}$ & $\begin{array}{l}4 \\
(2.9)\end{array}$ & - & - \\
\hline $\begin{array}{l}\text { Pelvic pain } \\
(n=82)\end{array}$ & 6 & 10 & - & 18 & 22 & 16 & $\begin{array}{l}6 \\
(7.3)\end{array}$ & $\begin{array}{l}2 \\
(2.4)\end{array}$ & - & $2(2.4)$ \\
\hline AUB $(n=36)$ & 4 & 4 & - & 16 & - & 6 & $\begin{array}{l}6 \\
(16.7)\end{array}$ & $\begin{array}{l}2 \\
(5.6)\end{array}$ & - & - \\
\hline $\begin{array}{l}\text { Post-coital } \\
\text { bleeding } \\
(\mathrm{n}=18)\end{array}$ & - & - & - & 6 & 2 & 4 & 2 & - & $\begin{array}{l}4 \\
(22)\end{array}$ & - \\
\hline $\begin{array}{l}\text { Mass per } \\
\text { vaginum } \\
(n=12)\end{array}$ & - & - & - & 2 & 4 & 6 & - & - & - & - \\
\hline $\begin{array}{l}\text { Post- } \\
\text { menopausal } \\
\text { bleeding } \\
(\mathrm{n}=10)\end{array}$ & - & - & - & 2 & 2 & - & 2 & 4 & - & - \\
\hline $\begin{array}{l}\text { Dysmenorrhe } \\
\text { a }(n=8)\end{array}$ & 4 & - & 2 & - & - & 2 & - & - & - & - \\
\hline Total $(n=300)$ & $\begin{array}{l}28 \\
(9.3)\end{array}$ & $\begin{array}{l}38 \\
(12.7)\end{array}$ & $4(1.3)$ & $78(26)$ & $36(12)$ & $\begin{array}{l}58 \\
(19.3)\end{array}$ & $\begin{array}{l}40 \\
(13.3)\end{array}$ & $\begin{array}{l}12 \\
(4)\end{array}$ & $\begin{array}{l}4 \\
(1.3)\end{array}$ & $2(0.7)$ \\
\hline
\end{tabular}

\section{DISCUSSION}

Cervical cancer screening was proved to be an important part of preventive health care of women. Attempts are being made to improve the efficacy of the screening programme to decrease the morbidity and mortality due to cervical cancer. The cervical screening algorithm for benign cellular changes on Papsmear recommends treatment of infection if indicated and a repeat Pap smear in 4-6 months time, and, if the inflammatory changes still persist, to subject the patient to colposcopy. However, in practice, this is not followed, especially in developing countries like ours, where proper screening protocols are not available/followed. Hence, a good number of patients in the pre-malignant stage are being missed.

Obstetrician Gynecologists do not review the Pap smear result with the cytologists and $41 \%$ do nothing when inflammatory Pap smear is reported. Only $11 \%$ treat the infection and repeat Pap smear and 24\%treat infection and do not repeat Pap smear.

There are very few studies in the literature where the incidence of premalignant and malignant lesions was looked into in cases of inflammatory Pap smear. Inflammation can obscure few malignant cells and may result in high false negative rates and the same may be reduced by employing liquid based cytology. ${ }^{8}$ However, it was reported that liquid based cytology was not costeffective for developing countries and the recent studies did not report a statistically significant difference of accuracy between conventional Pap test and liquid based cytology. ${ }^{9}$ The main reason for false-negative reports of cytology were found to be sampling errors, with sampling errors as high as $42.5 \%$ being suboptimal and $17.5 \%$ being inadequate for interpretation. ${ }^{10} \mathrm{Mc}$ Lachlan et al studied the colposcopic features and biopsy results of 102 
women with persistent inflammatory Pap smears and found $19 \%$ cases of CIN 2 or worse. ${ }^{11}$ This is almost similar to the present study.

The mean age and parity in the present study was higher (37 years and 2.6) than that of Seckin et al, where the mean age was 30.2 years and the parity was 1.7 . The most common persistent inflammatory Pap smear subjected to colposcopy was presumed to be non-specific in the study of Seckinet al, as they did not specify on the type of inflammatory smear. ${ }^{6}$

In the present study, $92 \%$ were non-specific inflammation and only $8 \%$ were specific inflammation due to Trichomonas vaginalis, Candida albicans and bacterial vaginosis. Wilson et al included bacteriological cultures of cervico vaginal smears to diagnose specific infections and found an increased incidence of sexually transmitted infections in patients $<25$ years of age and in many showing abnormal colposcopic features in this age group. ${ }^{7}$ Colposcopy was normal in $9.3 \%$ of the patients in the present study, which was much lower than that of Seckin et al, who reported $29.1 \%$ to be normal. A very high percentage $(62.5 \%)$ of normal colposcopic findings was reported by Wilson et al in 96 patients of inflammatory Pap smears. This is in contrast with the results of the present study.

Colposcopic biopsy showed benign lesions in $48.2 \%$ of the cases in the study done by Seckin et al, which was lower than that reported in the present study. Seckin reported a very high incidence of HPV-related lesions $(64.5 \%)$ where as Frisch reported an incidence of only $8 \% .^{12}$ HPV related lesions constituted only $19.4 \%$ in the present study. The incidence of pre-malignant lesions in the present study $(20.9 \%)$ was closer to that of Frisch $(23.5 \%)$ but much higher than that of Seckin et al $(8 \%-$ 18 out of 224). There were no cases of malignancy in the series of Seckin and Frisch but in the present study, one case was found. Recently, Hammes et al evaluated the population of macrophages during the cervical malignant transformation and its influence on CIN in cervical biopsy specimens. They concluded that macrophage count and inflammation increased linearly with disease progression. Inflammation was present in $25 \%, 46.1 \%$, $58.4 \%$ and $89.3 \%$ of normal, Low grade squamous intraepithelial lesion (LGSIL), (High grade squamous intraepithelial lesion) HGSIL and squamous cell carcinoma, respectively. ${ }^{13}$

Seckin recommends colposcopic evaluation of patients with persistent inflammatory Pap smear despite therapy in any population in any part of the World. Frisch is of the opinion that colposcopy of women with cytologic diagnosis of inflammatory epithelial changes may be a useful way to detect otherwise unrecognized cases of CIN, and the present study highlights these statements.

\section{CONCLUSION}

Patients with persistent inflammatory Pap smears can harbour a high proportion of CIN and HPV infection and hence these patients will need further evaluation by colposcopy.

\section{Funding: No funding sources}

Conflict of interest: None declared

Ethical approval: The study was approved by the Institutional Ethics Committee

\section{REFERENCES}

1. Moss SF, Blaser MJ. Mechanisms of Disease: Inflammation and origins of cancer. Nat Clin Pract Oncol.2005;2(2):907.

2. Kiviat NB, Paavonen JA, Brockway J, Critchlow CW, Brunham RC, Stevens CE. Cytologicmanifestations of cervical and vaginal infections. I. Epithelial and Inflammatory changes. JAMA.1985;253(7):989-96.

3. Atikson KM. benign cellular changes. In: Bonfigilo T, Erogen YS, editors. Gynaecologic Cytopathology. Philadelphia: Lppincot Raven Publishers. 1997;3342.

4. ACOG Practice Bulletin. clinical management guidelines for Obstetrician and Gynecologist Cervical Cytology screening Obstet Gynecol. 2003;102:417-27.

5. Swinker M, Cutlip AC, Ogle D. A comparison of uterine cervical cytology and biopsy results: Indications and outcome of Colposcopy. J Fam Pract. 1994;38:404.

6. Seckin NC, Turban NO, Ozmen S, Ersan F, Avsar F, Ustin H. Routine evaluation of patients with persistent inflammatory cellular changes on Pap smear. Int J Gynaecol Obstet. 1997;59(1):25-9.

7. Wilson JD, Robinson AJ, Kinghorn SA, Hicks DA. Implications of inflammatory changes on cervical cytology. BMJ. 1990;300(6725):638-40.

8. Marchand L, Van Dinter M, Mundt M, Dingel W, Klein G. Current cervical cancer screening practices of Dane Country, Wsconsin Primary care clinicians. WMJ. 2003;102(3):35-40.

9. ACOG Committee on Practice Bulletins-Gynecology. ACOG Practice Bulletin no. 109: Cervicalcytology screening. Obstet Gynecol. 2009;114(6):1409-20.

10. Vassilakos P. Management of Suboptimal Cytologic smears: Persistent inflammatory smears. Acta Cytol. 1998;42(6):1481.

11. Mc Lachalan N, Patwardhan JR, Ayer B, Pacey NF. Management of suboptimal cytologic smears: Persistent inflammatory smears. Acta Cytol. 1994;38(4) :5316.

12. Frisch LE, Parmar H, Buckley LD, Chalem SA. Colposcopy of patients with Cytologic Inflammatory epithelial changes. Acta Cytol. 1990; 34(2):133-5. 
13. Hammes LS, Tekamal RR, Naidu P, Edelweiss MI, Kirma N, Valentene PT, et al. Macrophages, inflammation and risk of cervical intraepithelial neoplaia (CIN) progression - Clinicopathological correlation. Gynecol Oncol. 2007;105(1):157-65.
Cite this article as: Verma B, Rastogi R, Srivastava D, Saharan S. Colposcopic evaluation of cervix with abnormal papsmear findings: prospective analytical study at our tertiary care centre. Int J Reprod Contracept Obstet Gynecol 2021;10:2036-41. 